\title{
Article \\ Effect of Grit Blasting and Polishing Pretreatments on the Microhardness, Adhesion and Corrosion Properties of Electrodeposited Ni-W/SiC Nanocomposite Coatings on 45 Steel Substrate
}

\author{
Bertrand Vigninou Gbenontin (D), Min Kang *(D), Ndumia Joseph Ndiithi, Samuel Mbugua Nyambura (D), \\ Emmanuel Awuah and Yin Zhang
}

check for updates

Citation: Gbenontin, B.V.; Kang, M.; Ndiithi, N.J.; Nyambura, S.M.; Awuah, E.; Zhang, Y. Effect of Grit Blasting and Polishing Pretreatments on the Microhardness, Adhesion and Corrosion Properties of Electrodeposited $\mathrm{Ni}-\mathrm{W} / \mathrm{SiC}$ Nanocomposite Coatings on 45 Steel Substrate. Crystals 2021, 11, 729. https://doi.org/10.3390/ cryst 11070729

Academic Editors: Marek Sroka,

Adam Zieliński and

Grzegorz Golański

Received: 6 June 2021

Accepted: 22 June 2021

Published: 24 June 2021

Publisher's Note: MDPI stays neutral with regard to jurisdictional claims in published maps and institutional affiliations.

Copyright: (c) 2021 by the authors. Licensee MDPI, Basel, Switzerland. This article is an open access article distributed under the terms and conditions of the Creative Commons Attribution (CC BY) license (https:/ / creativecommons.org/licenses/by/ $4.0 /)$.
College of Engineering, Nanjing Agricultural University, Nanjing 210031, China; 2019212016@njau.edu.cn (B.V.G.); 2020212023@stu.njau.edu.cn (N.J.N.); accessmbugua@gmail.com (S.M.N.); eawuah12@gmail.com (E.A.); 2018212003@njau.edu.cn (Y.Z.)

* Correspondence: kangmin@njau.edu.cn; Tel.: +86-25-5860-6667

\begin{abstract}
In this study, a grit-blasting pretreatment was used to improve the adhesion, corrosion resistance and microhardness of $\mathrm{Ni}-\mathrm{W} / \mathrm{SiC}$ nanocomposite coatings fabricated using the conventional electrodeposition technique. Prior to deposition, grit blasting and polishing (more commonly used) pretreatments were used to prepare the surface of the substrate and the 3D morphology of the pretreated substrates was characterized using laser scanning confocal microscopy. The coating surface and the cross-section morphology were analyzed using scanning electron microscopy (SEM). The chemical composition, crystalline structure, microhardness, adhesion and corrosion behavior of the deposited coatings were characterized using energy-dispersive spectroscopy (EDS), X-ray diffraction (XRD), a microhardness tester, a scratch tester and an electrochemical workstation, respectively. The results indicated that the grit blasting and $\mathrm{SiC}$ addition improved the microhardness, adhesion and corrosion resistance. The $\mathrm{Ni}-\mathrm{W} / \mathrm{SiC}$ nanocomposites pretreated by grit blasting exhibited the best adhesion strength, up to $36.5 \pm 0.75 \mathrm{~N}$. Its hardness was the highest and increased up to $673 \pm 5.47 \mathrm{Hv}$ and its corrosion resistance was the highest compared to the one pretreated by polishing.
\end{abstract}

Keywords: nano-composite; blasting; pretreatment; adhesion; microhardness; corrosion resistance

\section{Introduction}

The 45 steel is characterized by a good combination of mechanical properties as well as having low price in the market. Therefore, it is widely used for several components in mechanical engineering [1,2]. However, wear and corrosion are major reasons for failure of the mechanical parts in 45 steel during service. This limits its use in engineering fields where it is subjected to wear and corrosive environments. As such, it is necessary to improve the mechanical properties and corrosion resistance of this material [3-5].

Many surface-treatment techniques, such as hot dipping, surface hardening, thermal spraying, metallic cementation, nitrocarburizing, plasma nitriding, hard facing and electrodeposition [6-8], can be used to improve the microhardness, corrosion and wear resistance of 45 steel. Electrodeposition technology has been used extensively in recent years for the preparation of protective coatings because of its relatively lower cost, and it is also more convenient for engineering applications. This method has been used in the development of protective coatings that involves the coating of a metallic substrate with another metal or a combination of other metals (alloy coatings).

Among these coatings, the Ni-W alloy coating has caught the attention of researchers owing to its excellent corrosion resistance, high hardness and low toxicity, to replace hard chromium. In general, research carried out on electrodeposited Ni-W alloy coatings is aimed at improving their wear resistance, hardness and corrosion resistance [9-12]. In 
addition to the metal or alloy matrix, nanoparticles can be added to the coating so as to improve its mechanical and corrosion properties [13-17]. For this reason, many researchers have worked on Ni-W nanocomposite coatings and some studies have presented the performance of the incorporation of different nanoparticles in this binary alloy. One of these nanoparticles, $\mathrm{SiC}$, due to its high purity, small particle size and stable chemical properties, was used as second-phase reinforcing particles in a composite to improve the corrosion resistance, wear resistance and microhardness of the deposited coatings [18].

Furthermore, a number of investigations have been performed on the electrodeposition of the $\mathrm{Ni}-\mathrm{W} / \mathrm{SiC}$ composite coatings and many of them have been done using polishing pretreatment of the sample [19-21]. Currently, there are few studies available on the effects of the different pretreatment methods on the $\mathrm{Ni}-\mathrm{W} / \mathrm{SiC}$ nanocomposite. In many cases involving mechanical loading, failure mainly occurs at the interface between the coating and the substrate. According to past literature, the surface roughness of the substrate surface is increased at the macro-level by the blasting technique and this removes the inherent oxide layers that are present on the substrate surface. It also improves the interaction between the coating and substrate, thereby enhancing the adhesion, corrosion and wear-resistance properties [22-24]. Grit blasting has also been reported to impart nearsurface compressive residual stress, which decreases the effective applied stress during service as well as delaying formation and propagation of microcracks on the bulk material surface where the coating has a good adherence to the substrate surface and is free of defects and discontinuities [22]. It has been reported that the Ni-B coatings deposited on the $8620 \mathrm{H}$ steel substrates carried out with sandblasting by emery powders had the best adhesion strength and corrosion resistance [24].

In this study, $\mathrm{Ni}-\mathrm{W} / \mathrm{SiC}$ nanocomposite coatings were prepared by conventional electrodeposition. The effects of two different pretreatment processes (grit blasting and polishing pretreatment) on the coating adhesion, microhardness and corrosion resistance of the Ni-W/SiC nanocomposite coatings were studied. To the best of the authors' knowledge, this research has not been undertaken before.

\section{Materials and Methods}

$\mathrm{Ni}-\mathrm{W} / \mathrm{SiC}$ nanocomposite coatings were deposited on 45 steel samples measuring $30 \mathrm{~mm} \times 8 \mathrm{~mm} \times 7 \mathrm{~mm}$ using the conventional electrodeposition technique. For the first phase, steel samples were pretreated using the grit blasting technique and then rinsed thoroughly in an electrostatic agitator using double-distilled water to remove any loose metal pieces. The grit-blasted samples (Figure 1a) were subjected to a triple-immersion pretreatment process for electric cleaning. They were then immersed into the electrolyte for the deposition process. Grit blasting was performed using an abrasive grit blasting machine having a nozzle diameter of $8 \mathrm{~mm}, 1 \mathrm{~mm}$ steel grit particles, stand-off-distance of $100 \mathrm{~mm}$ and a blasting angle of $45^{\circ}$ at a pressure of $0.6 \mathrm{MPa}$. The schematic diagram of the grit blasting nozzle and substrate is shown in Figure 2.

For comparison purposes, the $\mathrm{Ni}-\mathrm{W} / \mathrm{SiC}$ nanocomposite coatings were also deposited on 45 steel substrates pretreated using the polishing pretreatment process (Figure 1b). For this phase of the experiment, the substrates were mechanically polished using abrasive emery papers with different granulometry ranging from 320 to 2000 and then subjected to a triple-immersion pretreatment process for electric cleaning. This ensured a stronger bond between the coating and substrate surface. The pretreatment process comprised of degreasing using electro-hydrostatic fluid, removal of the oxide layer on the surface by passing using a strong activating solution, and lastly removal of carbon-black using a weak activating solution. Table 1 shows the degreasing solution and $\mathrm{HCl}$ pickling solution reagents that were used for the process. The electrodeposition process was carried out in a $1000 \mathrm{~mL}$ glass beaker, and the electrodes were immersed vertically into the aqueous electrolytic Watts solution, with a distance of $3 \mathrm{~cm}$ between them. 


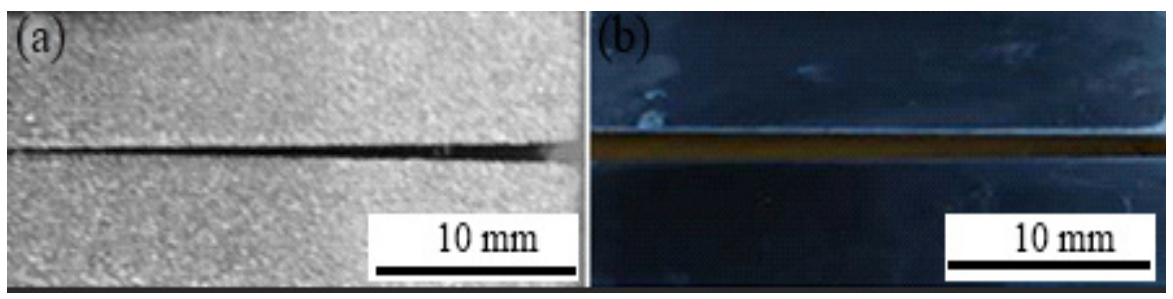

Figure 1. Photos of the prepared specimens: (a) grit-blasted samples; (b) polished samples.

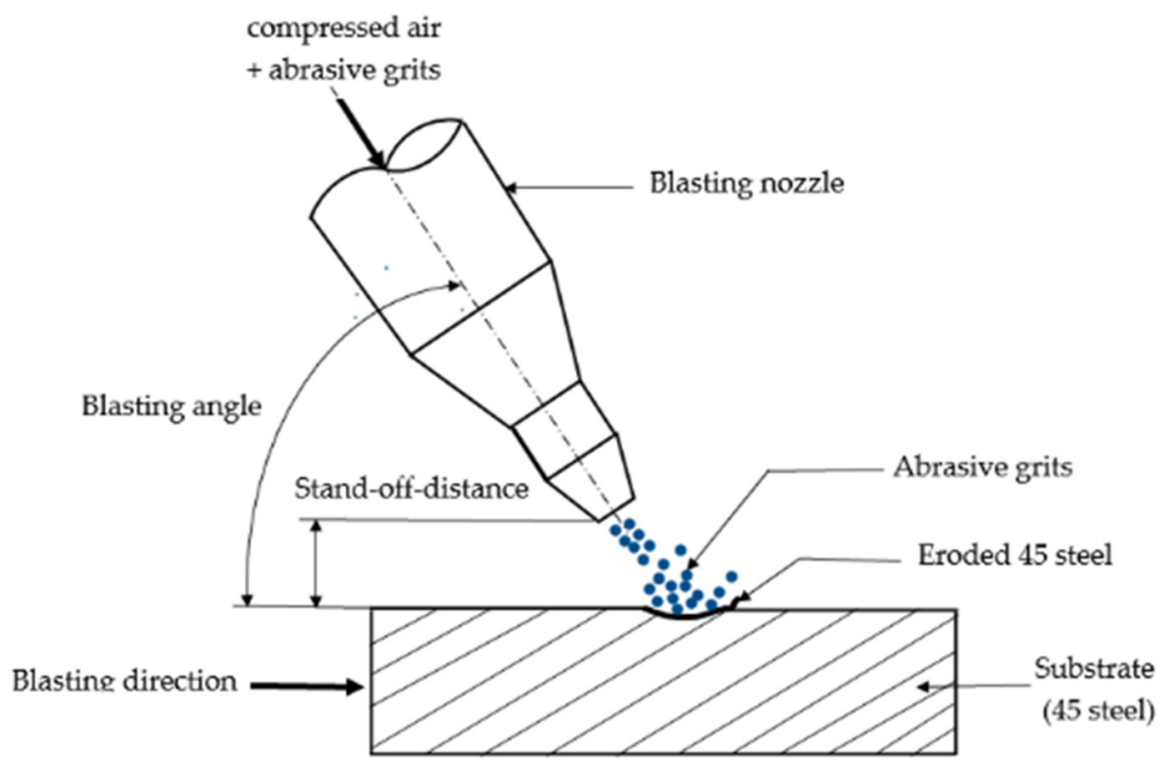

Figure 2. Schematic diagram of the grit blasting process.

Table 1. Pre-treatment process of the substrate surface.

\begin{tabular}{cccc}
\hline Process & Fluid Type & Chemical Composition & Concentration $\left.\mathbf{( g} \cdot \mathbf{L}^{-\mathbf{1}}\right)$ \\
\hline \multirow{4}{*}{ Degreasing } & & $\mathrm{NaOH}$ & 25 \\
& Electro-hydrostatic & $\mathrm{Na}_{2} \mathrm{CO}_{3}$ & 21.7 \\
& Fluid & $\mathrm{Na}_{3} \mathrm{PO}_{4}$ & 50 \\
& & $\mathrm{NaCl}$ & 2.4 \\
\cline { 2 - 4 } Pickling & Strong Activation & $\mathrm{HCl}$ & 25 \\
& Solution & $\mathrm{NaCl}$ & 140.1 \\
\cline { 2 - 4 } & \multirow{3}{*}{ Weak Activation } & $\mathrm{NaC}_{6} \mathrm{H}_{5} \mathrm{O}_{7} \cdot 2 \mathrm{H}_{2} \mathrm{O}$ & 141.2 \\
& Solution & $\mathrm{H}_{3} \mathrm{C}_{6} \mathrm{H}_{5} \mathrm{O}_{7} \cdot \mathrm{H}_{2} \mathrm{O}$ & 94.2 \\
& & $\mathrm{NiCl}_{2} \cdot \mathrm{H}_{2} \mathrm{O}$ & 3 \\
\hline
\end{tabular}

$\mathrm{SiC}$ nanoparticles with an average particle size of $40 \mathrm{~nm}$ were dispersed in an aqueous sulphate-citrate electrolyte. Prior to the deposition process, the solutions with SiC nanoparticles were stirred using a continuous magnetic stirrer at a rate of $360 \mathrm{rpm}$ for at least $24 \mathrm{~h}$ and subsequently by ultrasonic agitation for $30 \mathrm{~min}$ just prior to electrodeposition to ensure a uniform dispersion of $\mathrm{SiC}$ and prevent its agglomeration and settling. The same rate of magnetic stirring was also employed during electrodeposition at the cell bottom in order to maintain a homogeneous concentration of $\mathrm{SiC}$ particles in the solution. The reagents without any other form of purification were used in the electrolyte. Double-distilled water was used to prepare the electrolyte. The chemical composition of the electrolyte and the function of each component are shown in Table 2. 
Table 2. Chemical composition of the electrolyte bath.

\begin{tabular}{ccc}
\hline Bath Component & Concentration $\left(\mathbf{g} \cdot \mathbf{L}^{-\mathbf{1}}\right)$ & Function \\
\hline Nickel sulphate $\left(\mathrm{NiSO}_{4} \cdot 7 \mathrm{H}_{2} \mathrm{O}\right)$ & 18 & Ni source \\
Sodium tungstate & 46 & W source \\
$\left(\mathrm{Na}_{2} \mathrm{WO}_{4} \cdot 2 \mathrm{H}_{2} \mathrm{O}\right)$ & & \\
Trisodium citrate dihydrate & 145 & Complexer for Ni and W \\
$\left(\mathrm{Na}_{3} \mathrm{C}_{6} \mathrm{H}_{5} \mathrm{O}_{7} \cdot 2 \mathrm{H}_{2} \mathrm{O}\right)$ & 16 & Conductivity increase \\
Sodium bromide $(\mathrm{NaBr})$ & 0.3 & Surfactant \\
Sodium dodecyl sulphate $(\mathrm{SDS})$ & 26 & Buffer \\
Ammonium Chloride $\left(\mathrm{NH}_{4} \mathrm{Cl}\right)$ & $0,3,6,12$ & Nanoparticles \\
$\mathrm{SiC}(40 \mathrm{~nm})$ &
\end{tabular}

Table 3 shows the operating parameters used for preparing the Ni-W binary and $\mathrm{Ni}-\mathrm{W} / \mathrm{SiC}$ nanocomposite coatings.

Table 3. Electrodeposition parameters.

\begin{tabular}{cc}
\hline Deposition Parameters & Values \\
\hline Plating temperature $\left({ }^{\circ} \mathrm{C}\right)$ & 60 \\
Current density $\left(\mathrm{A} . d m^{-2}\right)$ & 5 \\
Stirring rate $(\mathrm{rpm})$ & 300 \\
$\mathrm{pH}$ & 7.5 \\
Electrodeposition time (min) & 60 \\
Current type & $\mathrm{DC}$ \\
Anode material & Pure Ni (99\%) \\
\hline
\end{tabular}

Apart from the different pretreatment processes used, the silicon carbide ( $\mathrm{SiC}$ ) nanoparticle concentration was varied, and its effect on the surface morphology, crystallite structure, microhardness, wear resistance, adhesion and corrosion resistance were analyzed, too. A laser scanning confocal microscope (LSCM, OLS4000, OLYMPUS, Tokyo, Japan) was used to analyze the 3D surface contour and roughness of the pretreated 45 steel samples. The coating morphology and microstructure of the deposited coatings was characterized using a FEI Quanta FEG 250 scanning electron microscope (SEM; Hillsboro, OR, USA). The SEM coupled with an energy-dispersive spectrometer (EDS Oxford max 20, Abingdon, UK) was used to determine the composition and the individual element content of the coatings.

X'Pert Power X-ray Diffraction (XRD, Westborough, MA, USA) with $\mathrm{Cu} K_{\alpha}$ radiation, operating at $40 \mathrm{kV}$ and $40 \mathrm{~mA}$, scanning from $20^{\circ}$ to $90^{\circ}$ with a step of $0.02^{\circ}$ was used to investigate the predominant crystallographic orientation, phase structure and grain size of the deposited coatings. Integral peak width was used to determine the average particle size. This can be expressed mathematically using the Debye-Scherrer formula shown in Equation (1).

$$
D=\frac{k \lambda}{\beta \operatorname{Cos} \theta} \cdot \frac{180^{\circ} \mathrm{C}}{\pi}
$$

where $D$ is the crystallite size, $\lambda$ represents the $X$-ray wavelength $(0.15406 \mathrm{~nm}), k$ the Scherrer constant, $\beta$ the full width at half maximum (rad) and $\theta$ the Bragg angle. The microhardness of the samples was measured using a Vickers microhardness tester (Struers, Duramin-40 A1, Ballerup, Copenhagen, Denmark), with an applied load of $100 \mathrm{~g}$ and an indentation time of $15 \mathrm{~s}$. Ten separate locations were randomly selected for each sample and an average was computed.

The coating adhesion was measured by a scratch tester. For the measurement of the critical load that the coating could withstand before it was peeled off from the substrate, a load from $0 \mathrm{~N}$ to $50 \mathrm{~N}$ was gradually applied to the coating.

Electrochemical corrosion measurements were analyzed by a potentiodynamic polarization test (Tafel) by using an electrochemical workstation comprising of a three-electrode cell in a $3.5 \mathrm{wt} . \% \mathrm{NaCl}$ medium. The slope of the potential-current density curve defining 
the polarization resistance $R p$ was obtained by the Stern-Geary equation. It is shown in Equation (2):

$$
R_{P}=\frac{\beta_{a} \times \beta_{c}}{2.303 i_{\text {corr }}\left(\beta_{a}+\beta_{c}\right)}
$$

where $\beta_{a}$ is the slope of the anodic Tafel reaction, $\beta_{c}$ represents the slope of the cathodic Tafel and $i_{\text {corr }}$ represents the corrosion current density. Electrochemical Impedance Spectroscopy (EIS) experiments were also carried out at the frequencies of $10^{5} \mathrm{~Hz}$ to $10^{-2} \mathrm{~Hz}$ at open circuit potential (OCP) where the amplitude of the perturbation voltage was $5 \mathrm{mV}$. Impedance measurements we represented in the form of Nyquist and Bode plots.

\section{Results}

\subsection{Surface Roughness}

Figure 3 shows the 3D surface morphology of the samples exposed to the polishing pretreatment and grit-blasting pretreatment. Observing Figure 3a, it can be seen that the surface of the 45 steel subjected to a polishing pre-treatment was smooth without undulations while the grit-blasted surface showed large undulations with an obvious mountain peak and ravine morphology (Figure $3 b$ ). The results show that the grit-blasting pretreatment could impart a rough appearance on the 45 steel surface. The surfaces roughness of the polished and grit-blasted substrates was evaluated. Table 4 contains the different roughness values (square root roughness (Sa) and mean square root roughness (Sq)) according to the different pretreatments. It can be seen that the values of the square root roughness of the 45 steel having undergone the polishing and grit-blasting pretreatment were $0.0047 \pm 0.0007 \mu \mathrm{m}$ and $1.0243 \pm 0.3 \mu \mathrm{m}$, respectively. While the mean square root roughness values were $0.0057 \pm 0.0007 \mu \mathrm{m}$, and $1.4237 \pm 0.410 \mu \mathrm{m}$, respectively, suggesting the enhanced effect of the grit blasting treatment on the surface roughness. Considering these different results, it appears that the surface roughness could be significantly increased by the use of a grit-blasting pretreatment. This was found to be in agreement with the results reported in a previous study by the authors [23,25-28].

(a)

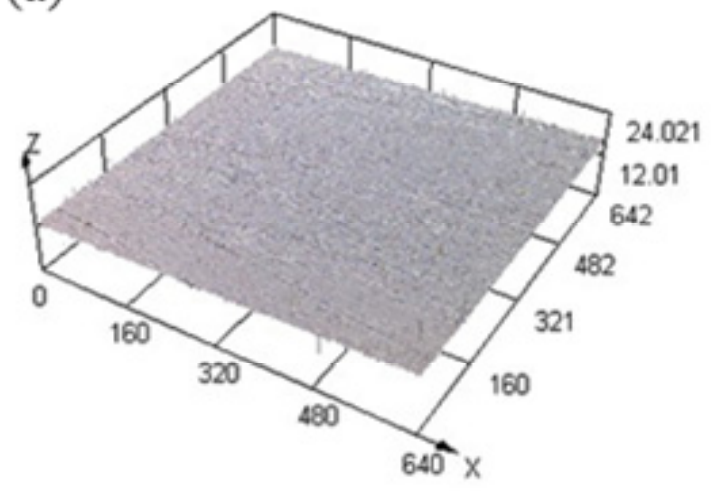

(b)

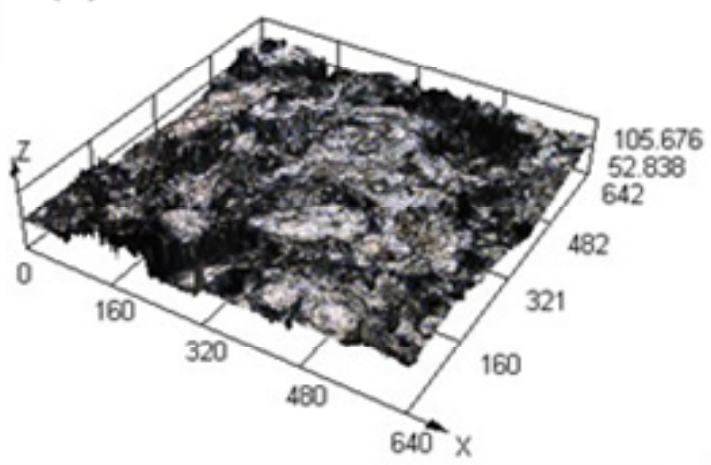

Figure 3. Surface 3D morphology of the substrates subjected to (a) polishing and (b) grit blasting.

Table 4. Surface roughness of the samples subjected to the polishing and grit-blasting pretreatment.

\begin{tabular}{ccc}
\hline Parameters & Polished Sample & Grit-Blasted Sample \\
\hline Sa $(\mu \mathrm{m})$ & $0.0047 \pm 0.0007$ & $1.0243 \pm 0.3$ \\
Sq $(\mu \mathrm{m})$ & $0.0057 \pm 0.0007$ & $1.4237 \pm 0.410$ \\
\hline
\end{tabular}

Previous studies have shown that a rough substrate surface was favorable for improving the thickness and adhesion of the coatings. Considering the work of Cheng et al. on the adhesion and corrosion resistance of nickel-boron coatings deposited on $8620 \mathrm{H}$ alloy 
steel, it can be seen that the coating thickness increased, with the best adhesion and best corrosion resistance achieved after the sandblasting pretreatment by emery powders [24].

\subsection{Surface Morphology}

SEM images of the surface morphologies of the grit-blasted, polished specimens and $\mathrm{Ni}-\mathrm{W}$ and $\mathrm{Ni}-\mathrm{W} / \mathrm{SiC}$ coatings on 45 steel substrates subjected to two different pretreatments, prepared by conventional electrodeposition, are shown in Figures 4 and 5. From Figures $4 \mathrm{a}$ and $5 \mathrm{a}$, it can be seen that a large number of random deformations in the form of bulges and pits were observed on the surface of the grit-blasted specimen, while the polished surface was flat and smooth with no scratches. Similar results were reported in previous studies $[29,30]$.

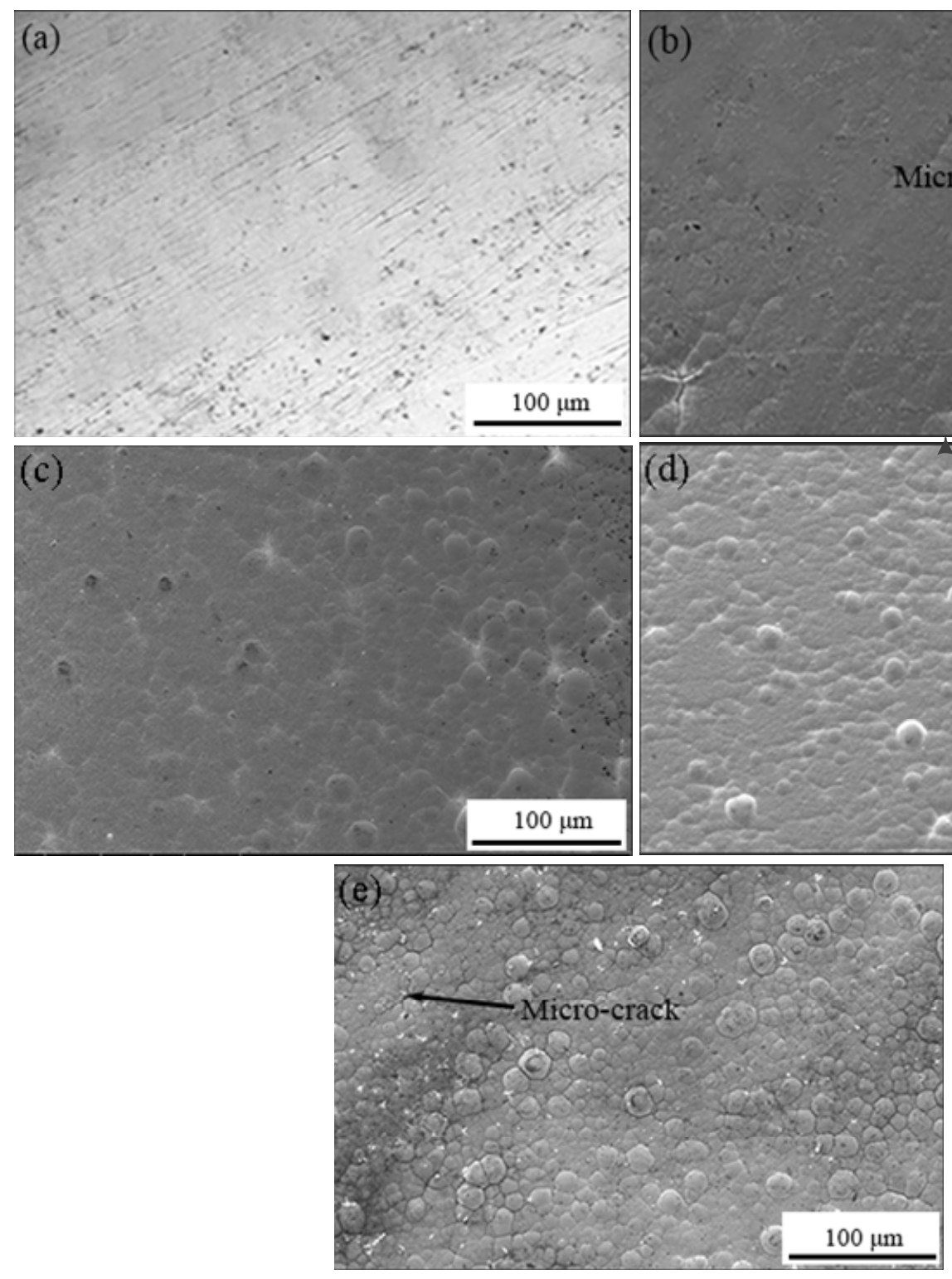

Figure 4. SEM micrographs of (a) the polished specimen, and the Ni-W/SiC nanocomposite coatings obtained at different $\mathrm{SiC}$ concentrations-(b) $0 \mathrm{~g} \mathrm{~L}^{-1}$, (c) $3 \mathrm{~g} \mathrm{~L}^{-1}$, (d) $6 \mathrm{~g} \mathrm{~L}^{-1}$ and (e) $12 \mathrm{~g} \mathrm{~L}^{-1}$ —on polished 45 steel substrate surfaces. 

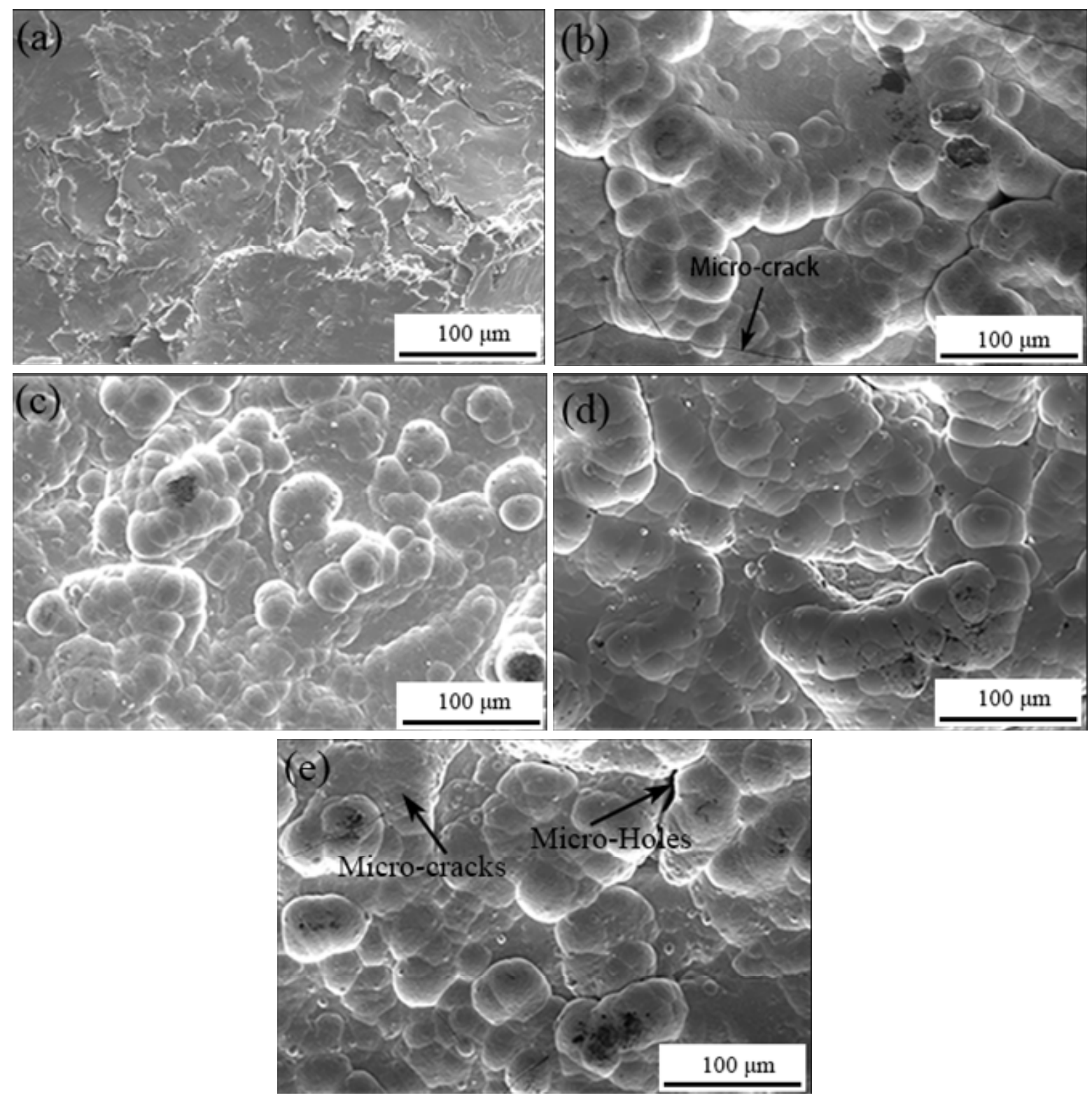

Figure 5. SEM micrographs of (a) the grit-blasted specimen and Ni-W/SiC nanocomposite coatings obtained at different $\mathrm{SiC}$ concentrations-(b) $0 \mathrm{~g} \mathrm{~L}^{-1}$, (c) $3 \mathrm{~g} \mathrm{~L}^{-1}$, (d) $6 \mathrm{~g} \mathrm{~L}^{-1}$ and (e) $12 \mathrm{~g} \mathrm{~L}^{-1}$ —on grit-blasted 45 steel substrate surfaces.

Figure $4 \mathrm{~b}$ presents the surface microstructure of the Ni-W coating. It shows that the coating had smooth, compact surface. It also exhibited nodular film with developing micro-cracks similar to the surface morphology of Ni-W films studied [16,31].

The Ni-W coating pretreated by polishing exhibited a less obvious nodular structure on the surface of the morphology which can be attributed to a lower surface roughness of the 45 steel substrates. Figure $5 \mathrm{~b}$ shows the surface microstructure of the Ni-W coating subjected to the grit-blasting pretreatment, where the cellular structure on the surface of the Ni-W coating was evident. The coating developed on the rough structure of the substrate during deposition and had bumps on the surface. With the presence of numerous bulges, hollows, and grain joints, and with the lattice defects generated by the grit-blasting pretreatment, the surface energy of the defects is relatively low, which allowed an easy surmounting of the energy barriers to nucleation. The number of nucleation sites then increased because of the defects generated after grit blasting [29,32]. Thus, the nucleation of the Ni-W alloy was easier after the grit-blasting pretreatment. 
These different results reveal that the roughness increased, and the nodule density was high in the case of the grit-blasting pretreatment; therefore, the number of nucleation points could be increased in the case of grit blasting. Similar results were reported by Liu et al. and Vitryn et al. [33,34].

Figures $4 c-e$ and $5 c-e$ present the SEM of the Ni-W/SiC coating fabricated on the substrate surface subjected to the polishing and grit-blasting pretreatments, respectively. From Figure $4 \mathrm{c}-\mathrm{e}$, it is evident that the Ni-W coating's surface morphology was influenced by the $\mathrm{SiC}$ nanoparticles. The $\mathrm{Ni}-\mathrm{W} / \mathrm{SiC}$ coatings on the polished substrate show that the addition of $\mathrm{SiC}$ nanoparticles in the bath results in a nodular morphology. Moreover, by increasing the $\mathrm{SiC}$ concentration, the nodularity increased. A similar morphology was obtained by Ahmadkhaniha et al. [35]. It appears that the increase in $\mathrm{SiC}$ nanoparticles further induced the formation of nucleation sites. Other researchers in their studies also observed the nodular morphology [31]. It can be seen that from $3-6 \mathrm{~g} \mathrm{~L}^{-1}$ of $\mathrm{SiC}$, the morphologies of the $\mathrm{Ni}-\mathrm{W} / \mathrm{SiC}$ coatings fabricated on the polished samples had no microcracks and defects but with $12 \mathrm{~g} \mathrm{~L}^{-1}$ of $\mathrm{SiC}$ the coating morphology contained some defects. Figure $5 c-$ e show the formation of a more cellular structure on the grit-blasted surface. The SiC nanoparticles not only facilitated increasing cathodic polarization and reduce the overpotential of the metal nucleation of $\mathrm{Ni}^{2+}$, but it also participated in the formation of new crystal nuclei, and prevented aggregation and growth of crystal grains during electroplating, such that the composite coating was refined [36].

The number of nucleation points on the cell structure of the $\mathrm{Ni}-\mathrm{W} / \mathrm{SiC}$ coating was the highest and its size was the smallest with regard to the grit-blasted substrate.

\subsection{Cross-Sectional Microstructure and EDS}

Figures 6 and 7 show the cross-sectional structure of the Ni-W and Ni-W/SiC nanocomposite coatings deposited on the polished and grit-blasted 45 steel, respectively.

The cross-sectional morphology of the Ni-W coating on the polished substrate is shown in Figure 6a. The coating was a uniform deposit on the surface of the smooth substrate with a thickness of about $17.35 \pm 0.39 \mu \mathrm{m}$. Figure 7a presents the cross-sectional morphology of the Ni-W coating on the grit-blasted substrate. There existed a tight bond between the coating and the rough surface of the substrate and the formation of a mechanical interlock resulting from the filling of the holes in the substrate. The thickness is approximately $18.45 \pm 0.53 \mu \mathrm{m}$, with pits up to $26.27 \mu \mathrm{m}$. Cheng et al. demonstrated that the increase in thickness observed is due to the high surface roughness caused by the grit blasting, which increased the number of nucleation points in the coating. Figure $6 \mathrm{~b}-\mathrm{d}$ shows cross sections of the $\mathrm{Ni}-\mathrm{W} / \mathrm{SiC}$ nanocomposite deposited on the polished 45 steel with the variation in the $\mathrm{SiC}$ nanoparticle concentration. With the increase in $\mathrm{SiC}$ particles from $3 \mathrm{~g} \mathrm{~L}^{-1}$ to $12 \mathrm{~g} \mathrm{~L}^{-1}$, the coatings exhibited a more compact cross section with good adhesion of the coating matrices to the substrate surface, and the coating thickness increased to $29.97 \pm 0.49 \mu \mathrm{m}$ at $6 \mathrm{~g} \mathrm{~L}^{-1}$ before decreasing to $20.95 \pm 0.88$ at $12 \mathrm{~g} \mathrm{~L}^{-1}$. A similar change in thickness as a function of the variation in the $\mathrm{SiC}$ concentration, as shown in Figure $8 \mathrm{a}$, was reported in previous research [37]. It can be suggested that by increasing the reinforced $\mathrm{SiC}$ nanoparticles from 6-12 $\mathrm{g} / \mathrm{L}$, it hindered the diffusion of the metallic ion through the electrolyte bulk to the cathode surface, thereby slowing down the growth rate [38].

Compared to the Ni-W coating, the thickness of all the Ni-W/SiC coatings was increased. This is due to the fact that the $\mathrm{SiC}$ particles refined the microstructure of the Ni-W coating and promoted its growth [36,39]. 

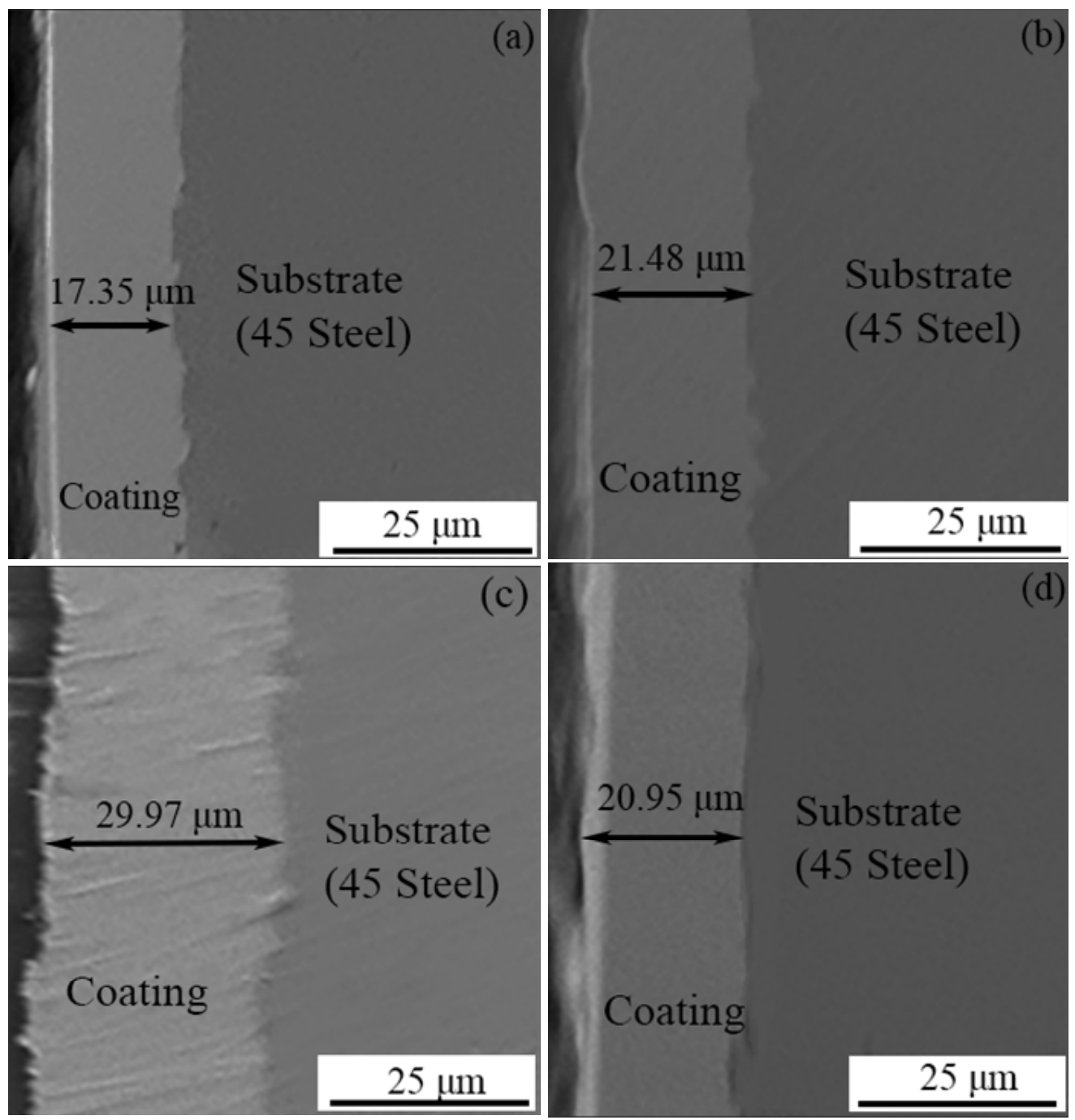

Figure 6. SEM micrographs, illustrating the coating cross section of the Ni-W/SiC nanocomposite coatings obtained at different $\mathrm{SiC}$ concentrations-(a) $0 \mathrm{~g} \mathrm{~L}^{-1}$, (b) $3 \mathrm{~g} \mathrm{~L}^{-1}$, (c) $6 \mathrm{~g} \mathrm{~L}^{-1}$ and (d) $12 \mathrm{~g} \mathrm{~L}^{-1}$-on polished 45 steel substrate surfaces.

Figure $6 \mathrm{~b}-\mathrm{d}$ shows cross sections of the $\mathrm{Ni}-\mathrm{W} / \mathrm{SiC}$ coatings, with variation in the $\mathrm{SiC}$ nanoparticle concentration, deposited on the grit-blasted 45 steel. With the increase in $\mathrm{SiC}$ particles from $3 \mathrm{~g} \mathrm{~L}^{-1}$ to $12 \mathrm{~g} \mathrm{~L}^{-1}$, the coating thickness increased to $25.9 \pm 1.5 \mu \mathrm{m}$ at $6 \mathrm{~g} \mathrm{~L}^{-1}$ before decreasing to $21.47 \pm 63 \mu \mathrm{m}$ at $12 \mathrm{~g} \mathrm{~L}^{-1}$. Compared with the Ni-W coating, the thickness of all the $\mathrm{Ni}-\mathrm{W} / \mathrm{SiC}$ coatings were increased. The change in thickness as a function of the variation in $\mathrm{SiC}$ concentration is shown in Figure $8 \mathrm{~b}$. The high adhesion to the rough substrate was due to the effect of the $\mathrm{SiC}$ nanoparticles. In addition, the valleys and apparent peaks appear on the surface of the substrate, which would have caused the densification of the nodular structure observed on the morphological surface shown in Figure 5c-e [24]. 


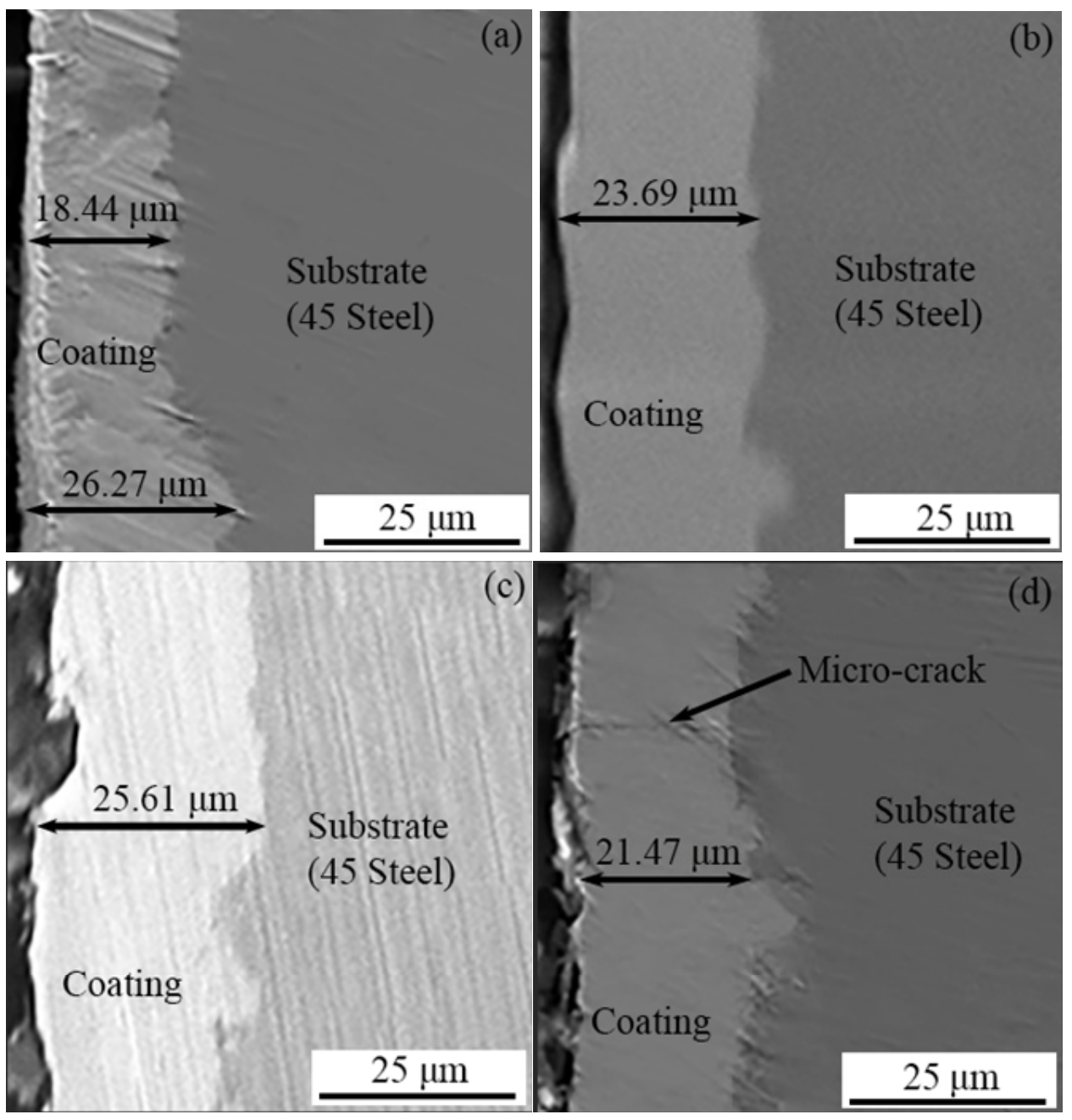

Figure 7. SEM micrographs illustrating coating cross sections of the $\mathrm{Ni}-\mathrm{W} / \mathrm{SiC}$ nanocomposite coatings obtained at different $\mathrm{SiC}$ concentrations-(a) $0 \mathrm{~g} \mathrm{~L}^{-1}$, (b) $3 \mathrm{~g} \mathrm{~L}^{-1}$, (c) $6 \mathrm{~g} \mathrm{~L}^{-1}$ and (d) $12 \mathrm{~g} \mathrm{~L}^{-1}$ - on grit-blasted 45 steel substrate surfaces.

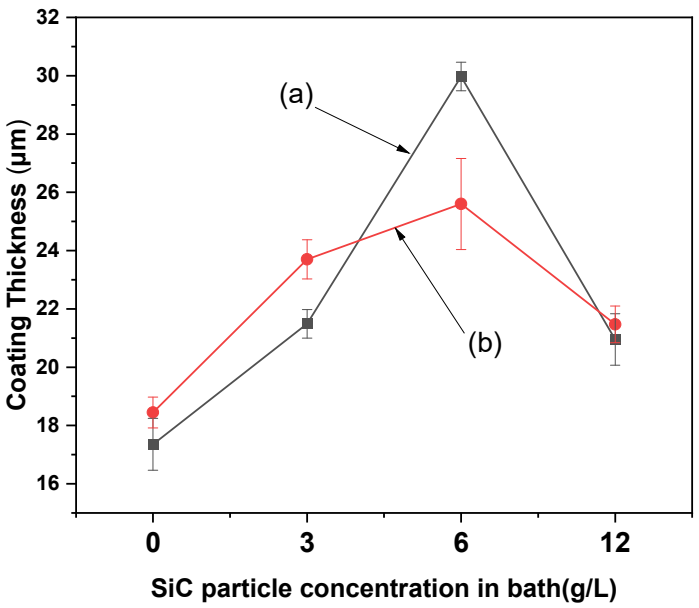

Figure 8. Thickness of the different $\mathrm{Ni}-\mathrm{W} / \mathrm{SiC}$ composite coatings fabricated on (a) polished and (b) grit-blasted 45 steel obtained at different $\mathrm{SiC}$ concentrations.

Figure 9 presents the EDS spectrum of the Ni-W coatings pretreated by polishing: $\mathrm{Ni}-\mathrm{W}(\mathrm{P})$; pretreated by grit blasting: $\mathrm{Ni}-\mathrm{W}(\mathrm{GB})$ and $\mathrm{Ni}-\mathrm{W} / \mathrm{SiC}$ nanocomposite coatings; 
pretreated by polishing: $\mathrm{Ni}-\mathrm{W} / \mathrm{SiC}(\mathrm{P})$; and grit-blasting pretreated: $\mathrm{Ni}-\mathrm{W} / \mathrm{SiC}(\mathrm{GB})$. As can be seen in Figure $9 a, b$, the EDS spectra of the Ni-W coatings prepared under the different processes present the peaks of $\mathrm{Ni}$ and $\mathrm{W}$, where the $\mathrm{Si}$ and $\mathrm{C}$ content were not found. As can be seen in Figure 9c,d, besides the Ni peaks, peaks corresponding to W and Si are also seen, and $\mathrm{C}$ is also visible in the all cases; that is, the $\mathrm{SiC}$ particles were successfully co-deposited in the Ni-W coatings. With polishing or grit-blasting pretreatments, the incorporation of $\mathrm{SiC}$ into $\mathrm{Ni}-\mathrm{W}$ reduced the amount of $\mathrm{Ni}$ and $\mathrm{W}$. According to Gyawali et al. [40], the decrease in $\mathrm{Ni}$ and $\mathrm{W}$ in the coating during the codeposition of $\mathrm{SiC}$ nanoparticles can be explained in terms of Faraday's efficiency. According to Figure 9c,d, the Ni-W/SiC $(\mathrm{P})$ $\left(6 \mathrm{~g} \mathrm{~L}^{-1}\right.$ of $\left.\mathrm{SiC}\right)$ coating has a lesser content of $\mathrm{W}(31.6 \mathrm{wt}$. \%) as compared to Ni-W/SiC(GB) $\left(6 \mathrm{~g} \mathrm{~L}^{-1}\right.$ of $\left.\mathrm{SiC}\right),(35.48 \mathrm{wt}$ \%). Moreover, the $\mathrm{SiC}$ content in all cases was low.

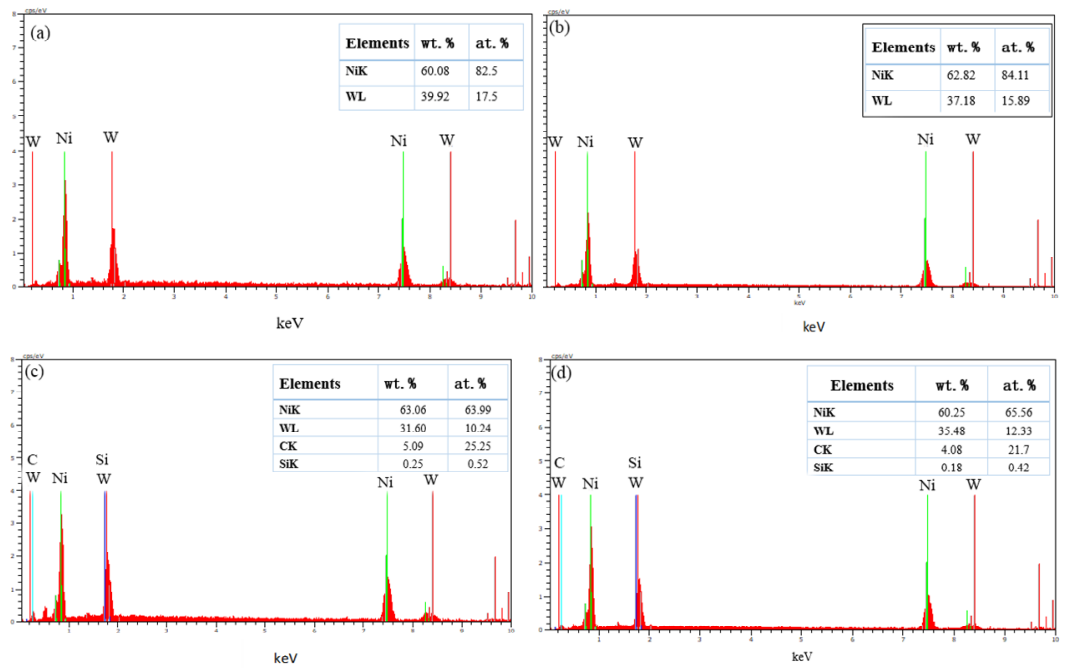

Figure 9. EDS spectra of (a) Ni-W(P), (b) Ni-W(GB), (c) Ni-W/SiC(P) and (d) Ni-W/SiC(GB).

\subsection{XRD Analysis}

Figures 10 and 11 show the XRD patterns of the Ni-W and Ni-W/SiC composite coatings on the polished and grit-blasted samples, respectively. In this study all the coatings have shown a face-centered cubic structure. In the polished samples, the peaks at $2 \theta$ equal to $43.72,50.94$ and 74.76 are associated with the (111), (200) and (220) Ni peaks, respectively, while in the case of the grit-blasted samples, the peaks at $2 \theta$ located to $43.55,50.83$ and 74.57 are associated with the (111), (200) and (220) Ni peak planes, respectively. The lattice parameters of the Ni-W solid solution are larger than those of the pure $\mathrm{Ni}$ coating. It had been noticed in the literature that the diffraction peaks of the Ni-W solid solution were shifted towards lower $2 \theta$ values compared to the positions of pure $\mathrm{Ni}$ [20]. With the increase in $\mathrm{SiC}$, the preferred orientation of the $\mathrm{Ni}-\mathrm{W} / \mathrm{SiC}$ coatings did not change significantly.

For both the grit blasting and polishing processes. The XRD results presented in Figures 10 and 11 show that the peaks corresponding to the SiC nanoparticles were not detected on the XRD pattern of the nanocomposite coatings but was confirmed by the EDS analysis. This was due to the low reinforcement content of the $\mathrm{SiC}$ nanoparticle in the deposited composite [40]. The crystallite size of the Ni-W alloy coating and of the $\mathrm{Ni}-\mathrm{W} / \mathrm{SiC}$ composite coatings was calculated using Scherer's equation and the grain values for the various electrodeposits are shown in Figure 12. The crystallite grain size of the $\mathrm{Ni}-\mathrm{W} / \mathrm{SiC}$ nanocomposite was observed to decrease as compared to the $\mathrm{Ni}-\mathrm{W}$ coating for all the pretreatment processes. 


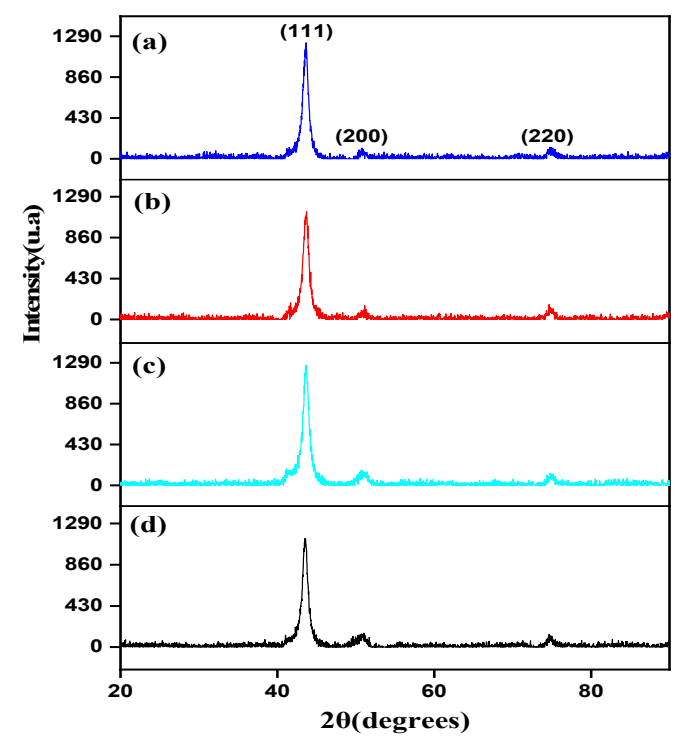

Figure 10. XRD patterns of $\mathrm{Ni}-\mathrm{W} / \mathrm{SiC}$ composite coatings on polished 45 steel obtained at different SiC concentrations: (a) $0 \mathrm{~g} \mathrm{~L}^{-1}$; (b) $3 \mathrm{~g} \mathrm{~L}^{-1}$; (c) $6 \mathrm{~g} \mathrm{~L}^{-1}$; (d) $12 \mathrm{~g} \mathrm{~L}^{-1}$.

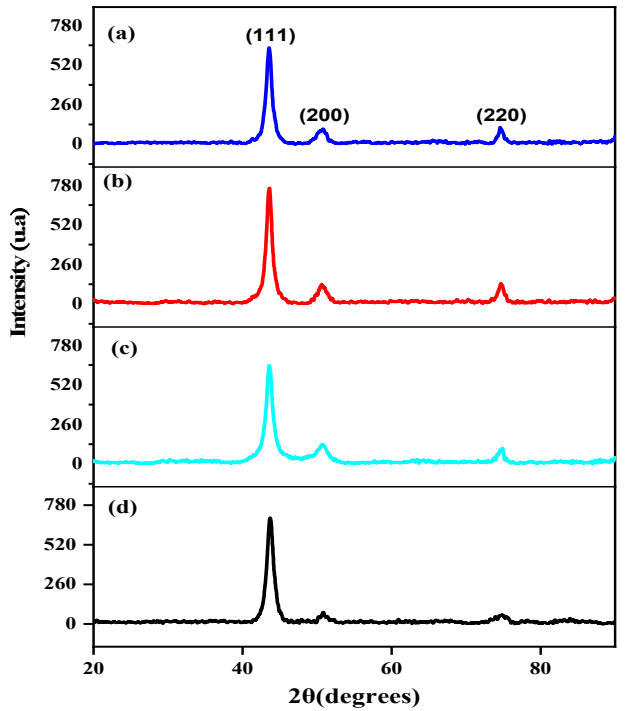

Figure 11. XRD patterns of $\mathrm{Ni}-\mathrm{W} / \mathrm{SiC}$ composite coatings on grit-blasted 45 steel obtained at different SiC concentrations: (a) $0 \mathrm{~g} \mathrm{~L}^{-1}$; (b) $3 \mathrm{~g} \mathrm{~L}^{-1}$; (c) $6 \mathrm{~g} \mathrm{~L}^{-1}$; (d) $12 \mathrm{~g} \mathrm{~L}^{-1}$.

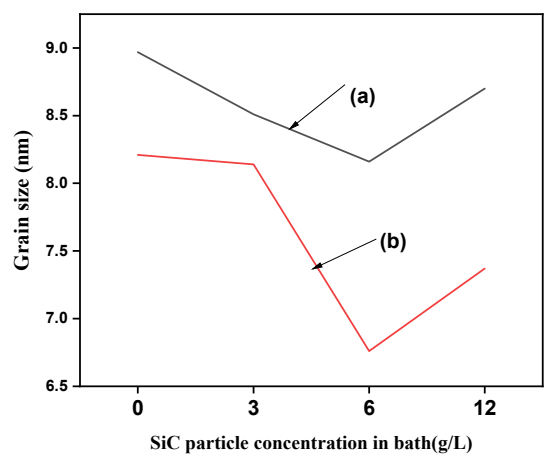

Figure 12. Grain sizes for different $\mathrm{Ni}-\mathrm{W} / \mathrm{SiC}$ composite coatings fabricated on (a) polished and (b) grit-blasted 45 steel obtained at different $\mathrm{SiC}$ concentrations. 
As shown in Figure 12a, the grain size of the $\mathrm{Ni}-\mathrm{W} / \mathrm{SiC}$ coatings obtained in the case of the polishing pretreatment process Figure 12a from the plating bath with different $\mathrm{SiC}$ nanoparticle concentration decreased with the increase in SiC concentration from $8.97 \mathrm{~nm}$ at $0 \mathrm{~g} \mathrm{~L}^{-1}$ to $8.16 \mathrm{~nm}$ at $6 \mathrm{~g} \mathrm{~L}^{-1}$ beyond which it increased to $8.7 \mathrm{~nm}$ at $12 \mathrm{~g} \mathrm{~L}^{-1}$. Concerning the grit-blasting pretreatment (Figure 12b), the grain size of the Ni-W/SiC coatings obtained from the plating bath with the different $\mathrm{SiC}$ nanoparticle concentration decreased with the increase in $\mathrm{SiC}$ concentration from $8.21 \mathrm{~nm}$ at $0 \mathrm{~g} \mathrm{~L}^{-1}$ to $6.76 \mathrm{~nm}$ at $6 \mathrm{~g} \mathrm{~L}^{-1}$ beyond which it increased to $7.37 \mathrm{~nm}$ at $12 \mathrm{~g} \mathrm{~L}^{-1}$. A similar trend was confirmed in previous publications [41-43]. From the result, the smallest grain size for both pretreatment processes was obtained at $6 \mathrm{~g} \mathrm{~L}^{-1}$.

According to the theory of electrodeposition, the nucleation rate and the rate of grain growth are the main basis for determining grain size. This is because the faster the nucleation rate, the slower the grain growth rate and the smaller the grains. The SiC nanoparticles added were absorbed at the cathode surface and created a large nucleation growth site favorable for coatings. The $\mathrm{SiC}$ nanoparticles were embedded in the metal grain boundaries of the Ni-W matrix and inhibited the growth of the grains, thereby reducing the size.

\subsection{Microhardness}

For objects subjected to a wear environment, two important properties of wear resistance and hardness are essential. Figure 13 presents the microhardness of the Ni-W/SiC nanocomposite coatings on the (a) polished and (b) grit-blasted 45 steel as a function of $\mathrm{SiC}$ concentration. It was noted that for the grit-blasting or polishing pretreatment processes, the microhardness increased with the increase in the concentration of $\mathrm{SiC}$, such that the microhardness of all the $\mathrm{Ni}-\mathrm{W} / \mathrm{SiC}$ nanocomposite coatings were higher than that of the $\mathrm{Ni}-\mathrm{W}$ coating alloy. Without $\mathrm{SiC}$, the deposited Ni-W exhibited the hardness for polishing and grit blasting of $550.25 \pm 7.04 \mathrm{Hv}$ and $589.89 \pm 10 \mathrm{Hv}$, respectively. The presence of $\mathrm{SiC}$ in the Ni-W coatings considerably increased the microhardness for all pretreatment processes. It is clear that an increase in the amount of $\mathrm{SiC}$ particle codeposition led to an increase in the hardness of the coatings. With an increase in the $\mathrm{SiC}$ concentration from 3 to $6 \mathrm{~g} \mathrm{~L}^{-1}$, the microhardness increased for the polishing and grit-blasting processes to $639.12 \pm 5.76 \mathrm{Hv}$ and $673 \pm 5.47 \mathrm{Hv}$, respectively, before decreasing when the concentration of $\mathrm{SiC}$ was increased from 6 to $12 \mathrm{~g} \mathrm{~L}^{-1}$. This effect of the nanoparticle on the coatings alloys has been described in previous research [15,44-46]. One possible reason for this result is that the $\mathrm{SiC}$ nanoparticles in the $\mathrm{Ni}-\mathrm{W} / \mathrm{SiC}$ coating blocked the dislocation movement and sliding at the grain boundary of the matrix, thereby increasing the micro-hardness of the Ni-W/SiC. The alloy matrix strengthening mechanism is mainly due to grain refinement, particle strengthening and dispersion hardening effects [42]. The higest hardness was obtained with the nanocomposite with the lowest grain size of $6.76 \mathrm{~nm}$.

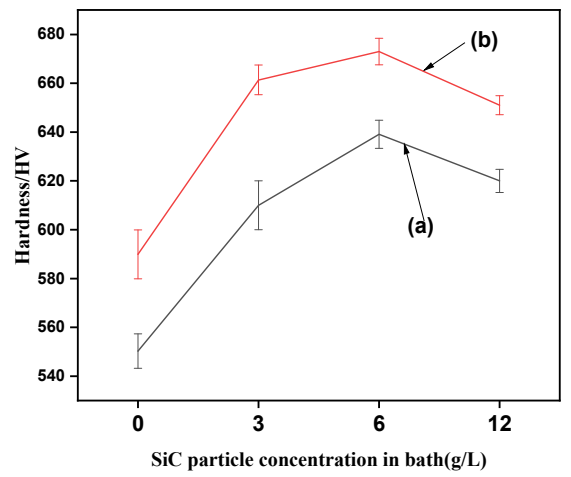

Figure 13. The microhardness values for of $\mathrm{Ni}-\mathrm{W}$ and $\mathrm{Ni}-\mathrm{W} / \mathrm{SiC}$ coatings on 45 steel substrates subjected to (a) polishing and (b) grit-blasting pretreatments by varying the SiC concentration in the electrolyte. 


\subsection{Coating Adhesion}

Figure 14 shows the adhesion of the coatings prepared on 45 steel substrates by electrodeposition with different pretreatment processes and by varying the $\mathrm{SiC}$ concentration. One of the important factors that degrades the protective performance and corrosion process of coatings is adhesion. Therefore, poor adhesion can cause performance failure of the $\mathrm{Ni}-\mathrm{W} / \mathrm{SiC}$ coatings. It was found that the adhesion of Ni-W alloys was not deteriorated by nanoparticles in any case whether the substrate was pretreated by polishing or by grit blasting. The addition of $\mathrm{SiC}$ inhibited the growth of the $\mathrm{Ni}-\mathrm{W}$ grain, and the grain size of the coating was refined. The effective contact area between the coating and the substrate increased and based on the mechanism of the dispersal reinforcement of the nanoparticles, the adhesion of the coatings improved [47]. The adhesion of the Ni-W alloy coating on the polished and grit-blasted substrates was $11.25 \mathrm{~N}$ and $14.25 \mathrm{~N}$, respectively. The Ni-W coating adhesion of the polished substrate was lower than that of the grit-blasted substrate. This remark is due to the rough surface obtained after blasting, which leads to the extrusion of the protrusions in the scratches. Fu et al. [27] studied the influence of the region of penetration elements on the adhesion and corrosion performance of the Ni-based coatings and indicated pre-processing by sanding increased the effective contact surface between the substrate and the coating and participated in the widening of the area of penetration of the element, which led to improved adhesion of the coating. Moreover, the grit-blasted surface has a larger contact area and better conditions for mechanical anchoring of the coating. Cheng et al. [24] found that the high surface roughness of the surfaces provided the higher adhesion force. Whether in the polishing or grit-blasting pretreatment, with the addition of the nano-SiC particles from 3-6 g L ${ }^{-1}$, the adhesion of the composite coatings gradually increased before decreasing when the nano-SiC concentration was from 6 to $12 \mathrm{~g} \mathrm{~L}^{-1}$. After the polishing pretreatment, the adhesion of the Ni-W/SiC coating increased to $26 \pm 0.5 \mathrm{~N}$ (SiC of $6 \mathrm{~g} \mathrm{~L}^{-1}$ ) before decreasing to $13 \mathrm{~N}\left(12 \mathrm{~g} \mathrm{~L}^{-1}\right.$ of $\left.\mathrm{SiC}\right)$. This effect of the $\mathrm{SiC}$ nano-particles was confirmed by the previous studies [37,45]. Adhesion obtained after

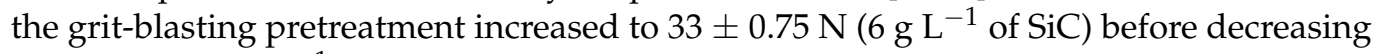
to $28 \pm 1 \mathrm{~N}\left(12 \mathrm{~g} \mathrm{~L}^{-1}\right.$ of $\left.\mathrm{SiC}\right)$. This indicates an improvement in the interface bond strength between the coating and the metal substrate. This may be due to the high hardness of the $\mathrm{SiC}$ nanoparticles, which played a major role in the coupling of the matrix [20]. It should be noted that the fact that the size of the Ni-W crystal is much larger than those of the $\mathrm{SiC}$ nanoparticles, as the $\mathrm{SiC}$ nanoparticles could fill the pores between the grains of the $\mathrm{Ni}-\mathrm{W}$ deposits, which could participate in the reduction of the porosity and improve the compactness of the coating. The metal matrix with a fine grain had a relatively high yield strength, according to the Hall-Petch equation $[48,49]$. The finer the size of the grain the larger the grain limit and this hinders the dislocation movement. Thus, the accumulation of dislocation at the boundary of the grain led to an increase in the strength of the coating. This remark is confirmed in Figures 12 and 15. In this study, the coatings with the small grain size had better coating adhesion for both the polishing and grit-blasting pretreatments.

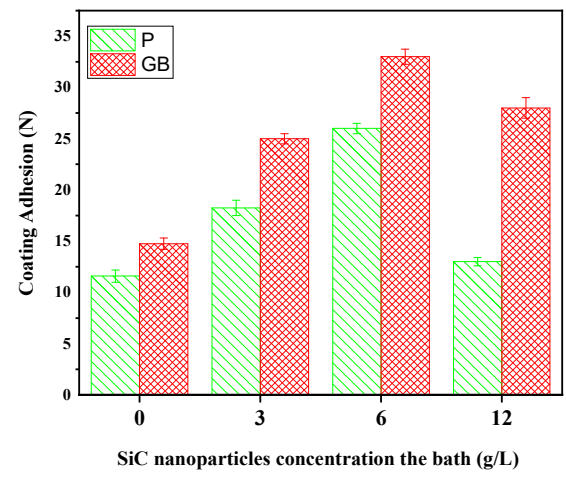

Figure 14. The analysis of critical load of the Ni-W and Ni-W/SiC composite coatings on 45 steel substrates subjected to the grit-blasting pretreatment by varying the $\mathrm{SiC}$ concentration in the electrolyte. 


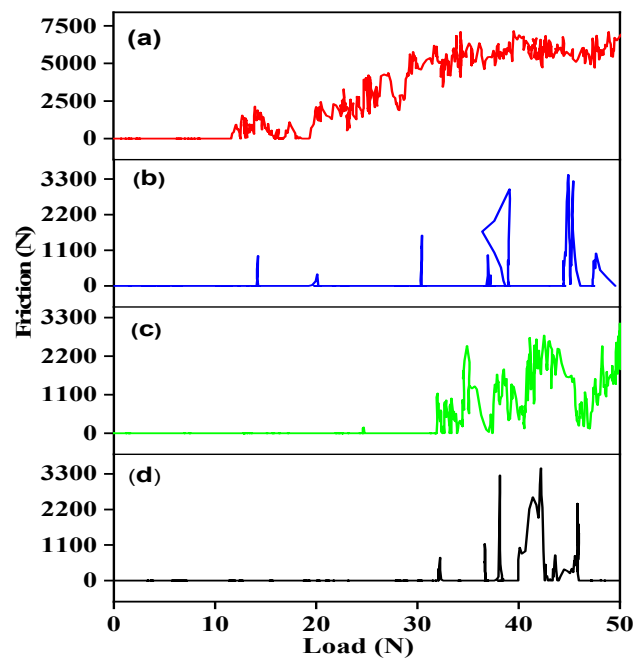

Figure 15. Shows the adhesion strength test curves measured by the scratch tester: (a) Ni-W(P), (b) Ni-W(GP), (c) Ni-W/6SiC(P) and (d) Ni-W/6SiC(GB).

\subsection{Corrosion Resistance}

Figure 16 shows the polarization curves of coatings fabricated on 45 steel substrates subjected to the different pretreatment processes. The extrapolation method was to determine the corrosion potential $\left(E_{\text {corr }}\right)$, corrosion current density $\left(i_{c o r r}\right)$, the polarization resistance $\left(R_{p}\right)$ and corrosion rate $\left(r_{c o r r}\right)$, as shown in Table 5 . The results show that, compared to polished samples, the corrosion potential of the grit-blasted substrate increased from -957 to $-830 \mathrm{mV}$, and the polarization resistance increased from -957 to $-830 \mathrm{mV}$, implying pre-treatment by grit blasting improved significantly the substrate's surface corrosion resistance. This is because after pre-processing by grit blasting, a rough structure was generated and after the infiltration of the corrosion products they could not be easily diffused. Similar results were found by $\mathrm{Fu}$ et al. and Zhang et al. [27,30]. Compared with the base substrate, it was found that the corrosion potential of the Ni-W coating was significantly greater than that of the substrate. In addition, the polarization resistance of the $\mathrm{Ni}-\mathrm{W}$ coating far exceeded that of the substrate and the corrosion rate decreased, too. This result shows that the $\mathrm{Ni}-\mathrm{W}$ coating was an effective protection against corrosion of the exposed base substrate. Moreover, compared with the polishing pretreatment, the Ni-W(GB) coating alloy exhibited $-696 \mathrm{mV}(-744 \mathrm{mV}$ for polishing) as the potential corrosion and $11.4 \mathrm{k} \Omega \mathrm{cm}^{-2}$ as polarization resistance value and $2.13 \mathrm{k} \Omega \mathrm{cm}^{-2}$ for $\mathrm{Ni}-\mathrm{W}(\mathrm{P})$. According to Fu et al. [27], this positive effect of the Ni-W coating can be explained by the fact that there was the formation of the region of penetration of the elements between the Ni-W coating and the base substrate. Additionally, the increased adhesion of the coating caused by the application of the grit blasting is one of the factors that contributed to the improvement in the corrosion resistance of the coating. For both polishing and sandblasting, there was an increase in the corrosion potential and in the polarization resistance of the $\mathrm{Ni}-\mathrm{W} / \mathrm{SiC}$ nanocomposite coating compared to the $\mathrm{Ni}-\mathrm{W}$ alloy coating. The $\mathrm{Ni}-\mathrm{W} / 6 \mathrm{SiC}(\mathrm{GB})$ nanocomposite coating exhibited the highest corrosion potential Ecorr $(-560 \mathrm{mV})$ and the highest corrosion resistance $R p\left(12.7 \mathrm{k} \Omega \mathrm{cm}^{-2}\right)$ compared to the $\mathrm{Ni}-\mathrm{W} / 6 \mathrm{SiC}(\mathrm{P})$ nanocomposite coating. The EDS showed that the $\mathrm{SiC}$ particles were evenly distributed over the $\mathrm{Ni}-\mathrm{W} / \mathrm{SiC}$ nanocomposite, which resulted in the refining of the coating structure and the creation of an area that reduced the infiltration of the corrosion products. 


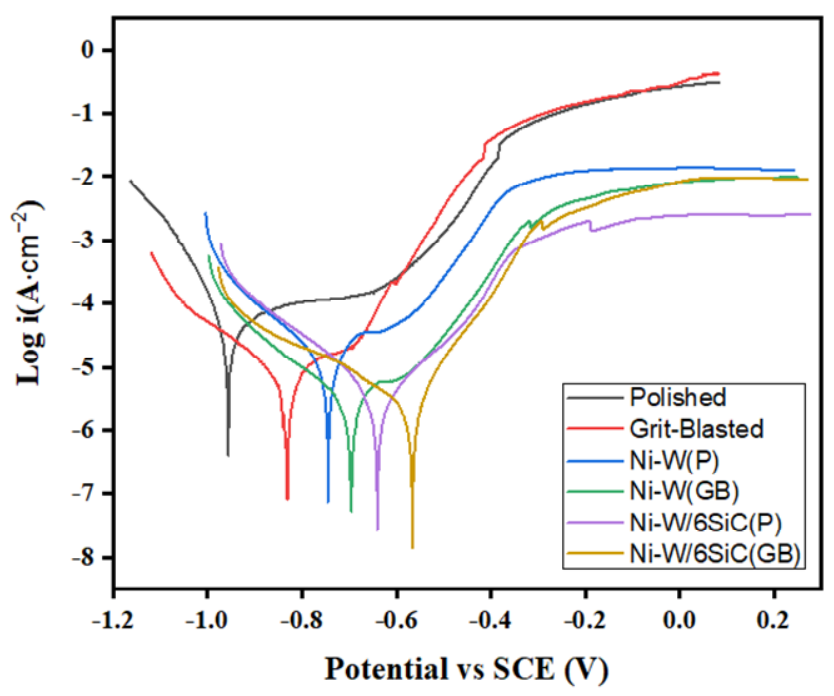

Figure 16. Polarization curves of the coatings prepared by scanning electrodeposition on 45 steel substrates with different pretreatment processes.

Table 5. Electrochemical data from the potentiodynamic polarization curves of the polished, gritblasted specimens and $\mathrm{Ni}-\mathrm{W} / \mathrm{SiC}$ coating on polished and grit-blasted 45 steels as a function of the $\mathrm{SiC}$ nanoparticle concentration in the electrolyte.

\begin{tabular}{|c|c|c|c|c|c|c|}
\hline Specimens & $\begin{array}{c}E_{\text {corr }} \\
\left(\mathrm{mV}_{\mathrm{SCE}}\right)\end{array}$ & $\left(\mu \mathrm{A} \mathrm{cm}^{i_{\text {corr }}} \mathrm{cm}^{-2}\right)$ & $\begin{array}{c}r_{\text {corr }} \\
\left(\mathrm{mm}^{-} \text {year }^{-1}\right)\end{array}$ & $\begin{array}{c}\beta_{a} \\
\left(\mathrm{mV} \operatorname{dec}^{-1}\right)\end{array}$ & $\begin{array}{c}\beta_{b} \\
\left(\mathrm{mV} \operatorname{dec}^{-1}\right)\end{array}$ & $\begin{array}{c}R_{p} \\
\left(\mathrm{k} \Omega \mathrm{cm}^{-2}\right)\end{array}$ \\
\hline Polished & -957 & 29 & 0.57 & 523.04 & 88.97 & 1.13 \\
\hline Grit-Blasted & -830 & 27.86 & 0.243 & 1212.5 & 429.82 & 4.95 \\
\hline Ni-W(P) & -744 & 19.3 & 0.17 & 181.42 & 193.01 & 2.13 \\
\hline Ni-W(GB) & -696 & 14.12 & 0.12 & 1507.7 & 489.62 & 11.4 \\
\hline $\mathrm{Ni}-\mathrm{W} / 6 \mathrm{SiC}(\mathrm{P})$ & -640 & 5.15 & 0.05 & 219.72 & 189.2 & 8.57 \\
\hline $\begin{array}{c}\mathrm{Ni}-\mathrm{W} / 6 \mathrm{SiC} \\
(\mathrm{GB})\end{array}$ & -560 & 3.71 & 0.03 & 155.2 & 357.24 & 12.7 \\
\hline
\end{tabular}

For supporting the findings from the potentiodynamic polarization, an additional corrosion resistance study of the $\mathrm{Ni}-\mathrm{W}$ and $\mathrm{Ni}-\mathrm{W} / \mathrm{SiC}$ coating under the different pretreatment processes was done by using a non-destructive electrochemical impedance spectroscopy (EIS) method to study the behavior of each sample in a $3.5 \mathrm{wt} \% \mathrm{NaCl}$ solution.

Figure 17 depicts the Nyquist and Bode plots recorded for the Ni-W and Ni-W/SiC coatings pretreated by the different processes. The increase in the impedance arc radius indicates that the coating had a better resistance to corrosion. The Nyquist plots were fitted using the ZSimpWin software; the results are listed in Table 6. The Figure 18 shows the equivalent electrical circuit, in which the Rs was the electrolyte resistance, CPEdl was the constant phase element and Rct represented the capacitive behavior at the interfaces of the coating/substrate. The results show that the grit-blasted substrate effectively improved the corrosion resistance seeing that after grit blasting, the Rct value increased from 0.665 to $0.940 \mathrm{k} \Omega \mathrm{cm}^{-2}$. The 45 steel had the smallest capacitive radius and, thus, the lowest corrosion resistance. Meanwhile, the $\mathrm{Ni}-\mathrm{W} / 6 \mathrm{SiC}(\mathrm{P})$ nanocoatings had a capacitive arc radius larger than the $\mathrm{Ni}-\mathrm{W}(\mathrm{P})$ ones. In addition, the $\mathrm{Ni}-\mathrm{W} / 6 \mathrm{SiC}(\mathrm{GB})$ nanocomposite coating, with an Rct value reaching $4.92 \mathrm{k} \Omega \mathrm{cm}^{-2}$, had the largest capacitive arc radius and had the highest corrosion resistance. The results of the EIS and the corrosion resistance obtained in the polarization curve had a similar trend. The Ni-W/SiC composite coating pre-treatment by grit blasting had the best corrosion resistance. 

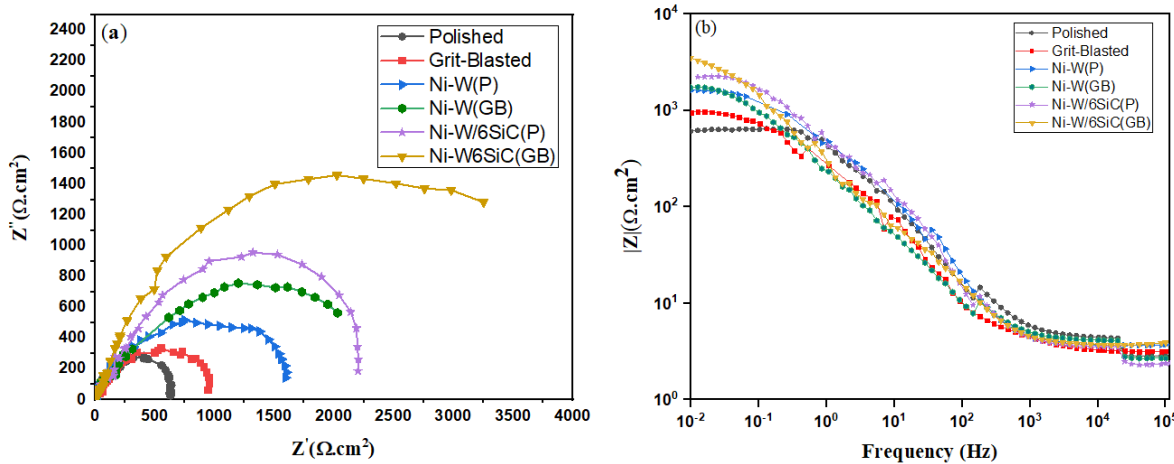

Figure 17. Electrochemical impedance spectra for the $\mathrm{Ni}-\mathrm{W}$ and $\mathrm{Ni}-\mathrm{W} / \mathrm{SiC}$ coatings on 45 steel substrates subjected to two different pretreatments in $3.5 \mathrm{NaCl}$ : (a) Nyquist plots; (b) Bode plots.

Table 6. The equivalent circuit parameters and fitting results of the impedance spectra of the Ni-W and $\mathrm{Ni}-\mathrm{W} / \mathrm{SiC}$ coatings pretreated by two different processes.

\begin{tabular}{ccccc}
\hline Specimens & $\boldsymbol{R}_{\boldsymbol{s}}\left(\boldsymbol{\Omega} \mathbf{~ c m}^{-\mathbf{2}}\right)$ & CPE-T $\left.\mathbf{( 1 0}^{-\mathbf{5}} \mathbf{F ~ c m}^{-\mathbf{2}}\right)$ & CPE-P & $\boldsymbol{R}_{\boldsymbol{c t}}\left(\mathbf{k} \boldsymbol{\Omega} \mathbf{~ c m}^{-\mathbf{2}}\right)$ \\
\hline Polished & 3.72 & 34.95 & 0.79 & 0.665 \\
Grit-Blasted & 3.14 & 68.04 & 0.77 & 0.940 \\
Ni-W(P) & 3.40 & 25 & 0.85 & 1.49 \\
Ni-W(GB) & 3.408 & 42.3 & 0.70 & 2.27 \\
Ni-W/6SiC(P) & 2.69 & 37 & 0.78 & 2.21 \\
Ni-W/6SiC (GB) & 3.427 & 86.6 & 0.703 & 4.92 \\
\hline
\end{tabular}

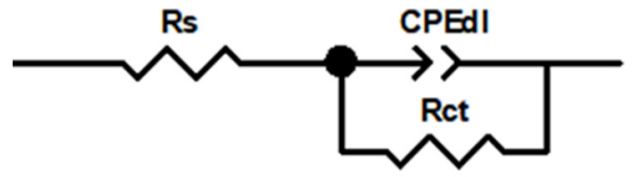

Figure 18. Equivalent circuit for the Nyquist plots analysis.

\section{Conclusions}

In this work, a Ni-W coating and $\mathrm{Ni}-\mathrm{W} / \mathrm{SiC}$ nanoparticle coating were fabricated on 45 steel substrates pretreated by polishing and sandblasting in order to study the effects of roughness and $\mathrm{SiC}$ nanoparticles on the microhardness, adhesion strength and corrosion resistance on the coatings. It can be concluded that grit blasting and $\mathrm{SiC}$ nanoparticles significantly strengthened the adhesion between the coating and the substrate. Meanwhile, the microhardness and the corrosion resistance improved.

(1) The $\mathrm{Ni}-\mathrm{W} / \mathrm{SiC}\left(6 \mathrm{~g} \mathrm{~L}^{-1}\right.$ of $\left.\mathrm{SiC}\right)$ nanocomposite fabricated on the grit-blasted 45 steel substrates exhibited the highest hardness compared to the one fabricated on polished 45 substrates.

(2) The adhesion of the $\mathrm{Ni}-\mathrm{W} / \mathrm{SiC}\left(6 \mathrm{~g} \mathrm{~L}^{-1}\right)$ nanocomposite coating pretreated by grit blasting was $33 \pm 0.75 \mathrm{~N}$, which was higher than the one pretreated by polishing.

(3) The $\mathrm{Ni}-\mathrm{W} / \mathrm{SiC}\left(6 \mathrm{~g} \mathrm{~L}^{-1}\right.$ of $\left.\mathrm{SiC}\right)$ nanocomposite fabricated on the grit-blasted 45 steel substrates exhibited the highest corrosion resistance compared to the one fabricated on polished 45 substrates.

Author Contributions: Conceptualization, B.V.G. and M.K.; methodology, B.V.G. and S.M.N.; software, B.V.G., E.A. and Y.Z.; validation, B.V.G., M.K. and N.J.N.; formal analysis, B.V.G. and N.J.N.; investigation, B.V.G., E.A. and S.M.N.; resources, M.K.; data curation, B.V.G., N.J.N. and E.A.; writing—original draft preparation, B.V.G. and S.M.N.; writing—review and editing, B.V.G. and M.K.; 
visualization, B.V.G., E.A. and N.J.N.; supervision, M.K.; project administration, M.K. and Y.Z.; funding acquisition, M.K. All authors have read and agreed to the published version of the manuscript.

Funding: The research was supported by Jiangsu Agricultural Science and Technology Innovation Fund CX(19)3071.

Data Availability Statement: The data that support the findings of this study are available from the corresponding author, upon reasonable demand.

Conflicts of Interest: The authors declare no conflict of interest.

\section{References}

1. Yan, M.; Zhu, W.Z. Surface Treatment of 45 Steel by Plasma-Arc Melting. Surf. Coat. Technol. 1997, 91, 183-191. [CrossRef]

2. Lu, Y.; Li, H.; Zhang, H.; Huang, G.; Xu, H.; Qin, Z.; Lu, X. Zr-Based Metallic Glass Coating for Corrosion Resistance Improvement of 45 Steel. Mater. Trans. 2017, 58, 1319-1321. [CrossRef]

3. Cai, W.; Meng, F.; Gao, X.; Hu, J. Effect of QPQ Nitriding Time on Wear and Corrosion Behavior of 45 Carbon Steel. Appl. Surf. Sci. 2012, 261, 411-414. [CrossRef]

4. Liu, H.; Wang, C.; Zhang, X.; Jiang, Y.; Cai, C.; Tang, S. Improving the Corrosion Resistance and Mechanical Property of 45 Steel Surface by Laser Cladding with Ni60CuMoW Alloy Powder. Surf. Coat. Technol. 2013, 228, S296-S300. [CrossRef]

5. Huang, G.; Qu, L.; Lu, Y.; Wang, Y.; Li, H.; Qin, Z.; Lu, X. Corrosion Resistance Improvement of 45 Steel by Fe-Based Amorphous Coating. Vacuum 2018, 153, 39-42. [CrossRef]

6. Holmberg, K.; Matthew, A.; Ronkainen, H. Chapter 2 Surface Coating Methods. In Tribology Series; Elsevier BV: Amsterdam, The Netherlands, 1994; Volume 28, pp. 7-32. [CrossRef]

7. Fotovvati, B.; Namdari, N.; Dehghanghadikolaei, A. On Coating Techniques for Surface Protection: A Review. J. Manuf. Mater. Process. 2019, 3, 28. [CrossRef]

8. Singh, S.; Garg, J.; Singh, P.; Singh, G.; Kumar, K.; Singh, J.; Kumar, S.; Singh, J.P. Effect of Hard Faced Cr-Alloy on Abrasive Wear of Low Carbon Rotavator Blades Using Design of Experiments. Mater. Today Proc. 2018, 5, 3390-3395. [CrossRef]

9. Chen, H.; Ren, X.R.; Zhang, X.H.; Li, J.H. Wear and Corrosion Properties of Crystalline Ni-W Alloy Coatings Prepared by Electrodeposition. Mater. Sci. 2016, 849, 671-676. [CrossRef]

10. Hu, Y.; Yu, Y.; Ge, H.; Wei, G.; Jiang, L. Study on Mechanical and Anticorrosion Performance of NiW Alloy Coatings Prepared by Induced Codeposition. Int. J. Electrochem. Sci. 2019, 14, 1649-1657. [CrossRef]

11. Elias, L.; Hegde, A.C. Effect of Magnetic Field on Corrosion Protection Efficacy of Ni-W Alloy Coatings. J. Alloys Compd. 2017, 712, 618-626. [CrossRef]

12. Pramod Kumar, U.; Liang, T.; Kennady, C.J.; Nandha Kumar, R.; Prabhu, J. Influence of Positional Isomeric Spacers of Naphthalene Derivatives on Ni-W Alloy Electrodeposition: Electrochemical and Microstructural Properties. ACS Omega 2020, 5, 3376-3388. [CrossRef] [PubMed]

13. Wasekar, N.P.; Latha, S.M.; Ramakrishna, M.; Rao, D.S.; Sundararajan, G. Pulsed Electrodeposition and Mechanical Properties of Ni-W/SiC Nano-Composite Coatings. Mater. Des. 2016, 112, 140-150. [CrossRef]

14. Zhang, W.; Ji, C.; Li, B. Synthesis and Properties of Ni-W/ZrO2 Nanocomposite Coating Fabricated by Pulse Electrodeposition. Results Phys. 2019, 13, 102242. [CrossRef]

15. Li, B.; Zhang, W. Microstructural, Surface and Electrochemical Properties of Pulse Electrodeposited Ni-W/Si3N4 Nanocomposite Coating. Ceram. Int. 2018, 44, 19907-19918. [CrossRef]

16. Allahyarzadeh, M.H.; Aliofkhazraei, M.; Rouhaghdam, A.R.S.; Torabinejad, V. Electrodeposition of Ni-W-Al2O3 Nanocomposite Coating with Functionally Graded Microstructure. J. Alloys Compd. 2016, 666, 217-226. [CrossRef]

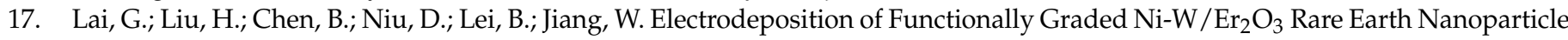
Composite Film. Int. J. Min. Met. Mater. 2020, 27, 818-829. [CrossRef]

18. Mbugua, N.S.; Kang, M.; Zhang, Y.; Ndiithi, N.J.; Bertrand, G.V.; Yao, L. Electrochemical Deposition of Ni, NiCo Alloy and NiCo-Ceramic Composite Coatings-A Critical Review. Materials 2020, 13, 3475. [CrossRef]

19. Hosseini, M.G.; Abdolmaleki, M.; Ghahremani, J. Investigation of Corrosion Resistance of Electrodeposited Ni-W/SiC Composite Coatings. Corros. Eng. Sci. Technol. 2014, 49, 247-253. [CrossRef]

20. Humam, S.B.; Gyawali, G.; Dhakal, D.R.; Choi, J.H.; Lee, S.W. Effect of Pulse and Direct Current Electrodeposition on Microstructure, Surface, and Scratch Resistance Properties of Ni-W Alloy and Ni-W-SiC Composite Coatings. Acta Met. Sin. 2020, 33, 1321-1330. [CrossRef]

21. Li, B.; Zhang, W.; Zhang, W.; Huan, Y. Preparation of Ni-W/SiC Nanocomposite Coatings by Electrochemical Deposition. J. Alloys Compd. 2017, 702, 38-50. [CrossRef]

22. Ghara, T.; Paul, S.; Bandyopadhyay, P.P. Effect of Grit Blasting Parameters on Surface and Near-Surface Properties of Different Metal Alloys. J. Therm. Spray Technol. 2021, 30, 251-269. [CrossRef]

23. Li, D.; Wu, J.; Miao, B.; Zhao, X.; Mao, C.; Wei, W.; Hu, J. Enhancement of Wear Resistance by Sand Blasting-Assisted Rapid Plasma Nitriding for 304 Austenitic Stainless Steel. Surf. Eng. 2020, 36, 524-530. [CrossRef] 
24. Cheng, A.Y.; Sheu, H.H.; Liu, Y.M.; Hou, K.H.; Hsieh, P.Y.; Ger, M. Der. Effect of Pretreatment Process on the Adhesion and Corrosion Resistance of Nickel-Boron Coatings Deposited on 8620H Alloy Steel. Int. J. Electrochem. Sci. 2020, 15, 68-79. [CrossRef]

25. Amiriafshar, M.; Rafieazad, M.; Duan, X.; Nasiri, A. Fabrication and Coating Adhesion Study of Superhydrophobic Stainless Steel Surfaces: The Effect of Substrate Surface Roughness. Surf. Interfaces 2020, 20, 100526. [CrossRef]

26. Arifvianto, B.; Mahardika, M. Effect of Sandblasting and Surface Mechanical Attrition Treatment on Surface Roughness, Wettability, and Microhardness Distribution of AISI 316L. Key Eng. Mater. 2011, 462-463, 738-743. [CrossRef]

27. Fu, X.; Shen, Z.; Chen, X.; Lin, J.; Cao, H. Influence of Element Penetration Region on Adhesion and Corrosion Performance of Ni-Base Coatings. Coatings 2020, 10, 895. [CrossRef]

28. Hammouda, N.; Belmokre, K. Effect of Surface Treatment by Sandblasting on the Quality and Electrochemical Corrosion Properties of a C-1020 Carbon Steel Used by an Algerian Oil Company. MATEC Web of Conference. In Proceedings of the 2018 2nd International Conference on Functional Materials and Chemical Engineering, Abu Dhabi, United Arab Emirates, 20-22 November 2018; Volume 272, p. 01001. [CrossRef]

29. Zhang, H.; Liu, Y.; Yuan, J.; Zhu, M.; Chen, J.; Wang, Z. The Influence of Substrate Surface Treatment on the Electrodeposition of $(\mathrm{Co}, \mathrm{Mn})_{3} \mathrm{O}_{4}$ Spinel Precursor Coatings. Mater. Res. Express 2020, 7, 076405. [CrossRef]

30. Zhang, Z.; Shen, Z.; Wu, H.; Li, L.; Fu, X. Study on Preparation of Superhydrophobic Ni-Co Coating and Corrosion Resistance by Sandblasting-Electrodeposition. Coatings 2020, 10, 1164. [CrossRef]

31. Nyambura, S.M.; Kang, M.; Zhu, J.; Liu, Y.; Zhang, Y.; Ndiithi, N.J. Synthesis and Characterization of Ni-W/Cr $\mathrm{O}_{3} \mathrm{Nanocomposite}$ Coatings Using Electrochemical Deposition Technique. Coatings 2019, 9, 815. [CrossRef]

32. Ding, L.; Torbati-Sarraf, H.; Poursaee, A. The Influence of the Sandblasting as a Surface Mechanical Attrition Treatment on the Electrochemical Behavior of Carbon Steel in Different PH Solutions. Surf. Coat. Technol. 2018, 352, 112-119. [CrossRef]

33. Liu, Z.; Gao, W. Electroless Nickel Plating on AZ91 Mg Alloy Substrate. Surf. Coat. Technol. 2006, 200, 5087-5093. [CrossRef]

34. Vitry, V.; Kanta, A.-F.; Delaunois, F. Initiation and Formation of Electroless Nickel-Boron Coatings on Mild Steel: Effect of Substrate Roughness. Mater. Sci. Eng. B 2010, 175, 266-273. [CrossRef]

35. Ahmadkhaniha, D.; Eriksson, F.; Leisner, P.; Zanella, C. Effect of SiC Particle Size and Heat-Treatment on Microhardness and Corrosion Resistance of NiP Electrodeposited Coatings. J. Alloys Compd. 2018, 769, 1080-1087. [CrossRef]

36. Jiang, W.; Shen, L.; Xu, M.; Wang, Z.; Tian, Z. Mechanical Properties and Corrosion Resistance of Ni-Co-SiC Composite Coatings by Magnetic Field-Induced Jet Electrodeposition. J. Alloys Compd. 2019, 791, 847-855. [CrossRef]

37. Temam, H.B.; Zeroual, L.; Chala, A.; Rahmane, S.; Nouveau, C. Microhardness and Corrosion Behavior of Ni-SiC Electrodeposited Coatings. Plasma Process. Polym. 2007, 4, S618-S621. [CrossRef]

38. Cabral-Miramonte, J.A.; Bastidas, D.M.; Baltazar, M.A.; Zambrano-Robledo, P.; Bastidas, J.M.; Almeraya-Calderón, F.M.; GaonaTiburcio, C. Corrosion Behavior of Zn-TiO2 and Zn-ZnO Electrodeposited Coatings in 3.5\% NaCl Solution. Int. J. Electrochem. Sci. 2019, 14, 4226-4239. [CrossRef]

39. Jin, P.; Sun, C.; Zhang, Z.; Zhou, C.; Williams, T. Fabrication of the Ni-W-SiC Thin Film by Pulse Electrodeposition. Surf. Coat. Technol. 2020, 392, 125738. [CrossRef]

40. Gyawali, G.; Tripathi, K.; Joshi, B.; Lee, S.W. Mechanical and Tribological Properties of Ni-W-TiB 2 Composite Coatings. J. Alloys Compd. 2017, 721, 757-763. [CrossRef]

41. Xing, S.; Wang, L.; Jiang, C.; Liu, H.; Zhu, W.; Ji, V. Influence of $\mathrm{Y}_{2} \mathrm{O}_{3}$ Nanoparticles on Microstructures and Properties of Electrodeposited Ni-W- $\mathrm{Y}_{2} \mathrm{O}_{3}$ Nanocrystalline Coatings. Vacuum 2020, 181, 109665. [CrossRef]

42. Fan, Y.; He, Y.; Luo, P.; Shi, T.; Chen, X. Pulse Current Electrodeposition and Properties of Ni-W-GO Composite Coatings. J. Electrochem. Soc. 2016, 163, D68-D73. [CrossRef]

43. Kumar, K.A.; Kalaignan, G.P.; Muralidharan, V.S. Direct and Pulse Current Electrodeposition of Ni-W-TiO $2 \mathrm{Nanocomposite}^{-}$ Coatings. Ceram. Int. 2013, 39, 2827-2834. [CrossRef]

44. Jiang, W.; Shen, L.; Qiu, M.; Wang, X.; Fan, M.; Tian, Z. Preparation of Ni-SiC Composite Coatings by Magnetic Field-Enhanced Jet Electrodeposition. J. Alloys Compd. 2018, 762, 115-124. [CrossRef]

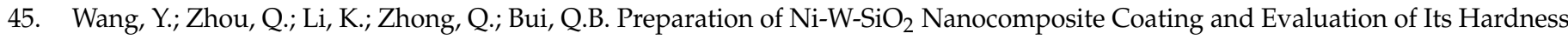
and Corrosion Resistance. Ceram. Int. 2015, 41, 79-84. [CrossRef]

46. Li, H.; He, Y.; Fan, Y.; Xu, W.; Yang, Q. Pulse Electrodeposition and Corrosion Behavior of Ni-W/MWCNT Nanocomposite Coatings. RSC Adv. 2015, 5, 68890-68899. [CrossRef]

47. Rogal, Ł.; Kalita, D.; Tarasek, A.; Bobrowski, P.; Czerwinski, F. Effect of SiC Nano-Particles on Microstructure and Mechanical Properties of the CoCrFeMnNi High Entropy Alloy. J. Alloys Compd. 2017, 708, 344-352. [CrossRef]

48. Yang, Y.; Cheng, Y.F. Mechanistic Aspects of Electrodeposition of Ni-Co-SiC Compositenano-Coating on Carbon Steel. Electrochim. Acta. 2013, 109, 638-644. [CrossRef]

49. Mahmudi, R. Grain Boundary Strengthening in a Fine Grained Aluminium Alloy. Scr. Met. Mater. 1995, 32, 781-786. [CrossRef] 